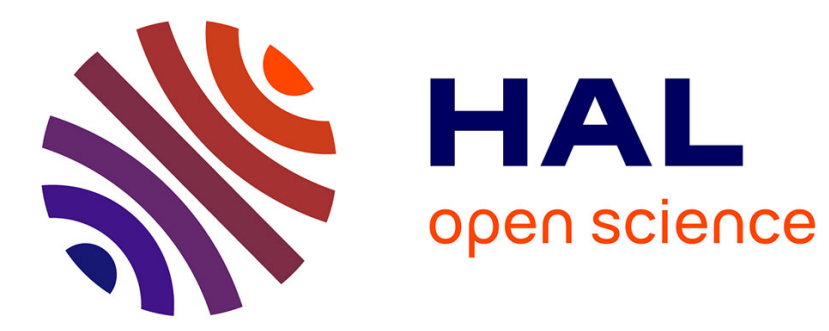

\title{
Répertoire des textes législatifs et réglementaires publiés pendant le mois de juin 1996
}

- [.]revue Forestière Française, Rédaction

\section{- To cite this version:}

- [.]revue Forestière Française, Rédaction. Répertoire des textes législatifs et réglementaires publiés pendant le mois de juin 1996. 1996, pp.391-391. 10.4267/2042/26761 . hal-03535442

\section{HAL Id: hal-03535442 \\ https://hal.science/hal-03535442}

Submitted on 19 Jan 2022

HAL is a multi-disciplinary open access archive for the deposit and dissemination of scientific research documents, whether they are published or not. The documents may come from teaching and research institutions in France or abroad, or from public or private research centers.
L'archive ouverte pluridisciplinaire HAL, est destinée au dépôt et à la diffusion de documents scientifiques de niveau recherche, publiés ou non, émanant des établissements d'enseignement et de recherche français ou étrangers, des laboratoires publics ou privés. 


\section{législation et \\ jurisprudence}

\section{RÉPERTOIRE DES TEXTES LÉGISLATIFS ET RÉGLEMENTAIRES PUBLIÉS PENDANT LE MOIS DE JUIN 1996}

\section{ENVIRONNEMENT}

\section{- Décrets}

Décret $n^{\circ}$ 96-491 du 6 juin 1996 portant création de la réserve naturelle de la Trinité (Guyane).

(J.O. Lois et Décrets, $n^{\circ} 131$ du 7 juin 1996, pp. 8423-8425).

Décret du 28 mai 1996 portant classement de sites.

(J.O. Lois et Décrets, $n^{\circ} 131$ du 7 juin 1996 , p. 8425$)$.

Montagne Pelée, pentes Nord-Ouest et littoral.

\section{PERSONNELS}

\section{- Arrêté}

Arrêté du 12 juin 1996 relatif à l'agrément des hommes de l'art pour l'établissement des projets de travaux forestiers et des plans simples de gestion.

(J.O. Lois et Décrets, $n^{\circ} 144$ du 22 juin 1996 pp. 9367-9368).

Dérogation. Possibilité, par l'entremise d'une coopérative, de faire appel à des ingénieurs ou techniciens non inscrits sur la liste des experts forestiers. 